\begin{abstract}
"Mircea cel Batran" Naval Academy Scientific Bulletin, Volume XIX - 2016 - Issue 1
Published by "Mircea cel Batran" Naval Academy Press, Constanta, Romania /I The journal is indexed in:

PROQUEST / DOAJ / DRJI / JOURNAL INDEX / I2OR / SCIENCE LIBRARY INDEX / Google Scholar / Crossref /

Academic Keys / ROAD Open Access / OAJI / Academic Resources / Scientific Indexing Services / SCIPIO
\end{abstract}

\title{
AN APPROACH TO WAVE ENERGY CONVERTER APPLICATIONS ON TURKEY AND THEIR ELECTRICITY GENERATION CAPACITY
}

\author{
Abdi KUKNER ${ }^{1}$ \\ Akile Nese HALILBESE ${ }^{2}$ \\ Sertac BULUT ${ }^{3}$ \\ ${ }^{1} \mathrm{PhD}$, Professor, Department of Shipbuilding and Ocean Engineering, Faculty of Naval Architecture and Ocean \\ Engineering, Istanbul Technical U., Istanbul, Turkey \\ ${ }^{2} \mathrm{PhD}$, Research Assistant, Department of Naval Architecture and Marine Eng., Faculty of Naval Architecture \\ and Ocean Eng., Istanbul Technical U., Istanbul, Turkey \\ ${ }^{3} \mathrm{PhD}$, Research Assistant, Department of Naval Architecture and Marine Eng., Faculty of Naval Architecture \\ and Ocean Eng., Istanbul Technical U., Istanbul, Turkey
}

\begin{abstract}
Increasing the amount of research on renewable wave energy in Turkey has been getting crucial recently to reduce its energy dependence on exhaustible natural energy resources. The purpose of this study is to determine the electrical energy potential obtainable from the wave energy converters in Turkey. Firstly, different type of wave energy conversion systems have been investigated and as a result of the review, the Oscillating Water Column (OWC) is considered to be most effective energy converter due to a suitable power generation system. The scope of the study is to evaluate and compare the wave energy potential between different regions of Turkey by using available wind and wave data. Five different coastal regions selected along the coastline of Black and Mediterranean Sea and lğneada is considered to be most effective region because of their highest wavelength. In addition, OWC is modeled as a system using the pressed air in a column and it is mathematically described as a difference in pressure and expressed by the Bernoulli equation. General equations of motion of a system subject to forced oscillation are derived, and then, the components of the damping coefficient are investigated by using the optimization theory. After that, the theory developed in the previous part has been applied to Iğneada Region in Black Sea. It is finally shown that how much electricity needs to be met by using OWC system.
\end{abstract}

Keywords: Wave energy; Renewable energy; Wave energy converters; Turkey; Black Sea; Analysis of energy generation

\section{INTRODUCTION}

There has been a significant increase in energy demandsdue to the population growth and economical, technological developments. Electrical energy production has been mainly derived from limited sources such as thermal and hydraulic in Turkey and most of the thermal sources are obtained from natural gas and coal. Turkey is a developing country and unfortunately highly dependent on exported energy resources such as natural gas; therefore, decreasing usage of natural gas is very important for both economic and environmental aspects.

The electric power produced via usage of renewable resources except hydroelectricity in 2007 is only $3 \%$ and it will be intended to increase this proportion up to $6 \%$ until 2030 [1]. Increasing the amount of investigation on renewable wave energy in Turkey has been getting crucial recently to reduce its energy dependence on exhaustible natural energy resources. Worldwide wind power is clearly at the forefront of the renewable energy sources. The total installed wind power capacity round the world by now stands over $60 \mathrm{GW}$. In 2006 only in the EU near 7.6 GW of wind power capacity was installed, worth over
9 billion $€$. This means an increase of $23 \%$ compared to 2005 [2]. Ocean energy is a yet unexploited renewable energy source on our planet. Preliminary surveys show that marine power has a potential to supply a significant part of the future European energy needs [3].The World Energy Council has estimated the global ocean wave energy over 2 TW (which means 17,500 TWh/year). From this it has been estimated that the practical economic contribution of the wave energy converters could be 2,000 TWh/year, similar to current installed nuclear or hydroelectric generation capacity. Such generating capacity could result in up to 2 billion tons of $\mathrm{CO}_{2}$ emissions being displaced from fossil fuel generation per year, similar to current emissions from electricity generation in the US [4]. The scope of the study is to evaluate and compare the wave energy potential between different regions of Turkey by using available wave data and wave energy converter system.

\section{THE WAVE POWER IN THE TURKEY}

This study focuses on wave energy potential along the Turkish coasts by using available wind and wave model data. Five different coastal regions 
"Mircea cel Batran" Naval Academy Scientific Bulletin, Volume XIX - 2016 - Issue 1

Published by "Mircea cel Batran" Naval Academy Press, Constanta, Romania // The journal is indexed in:

PROQUEST / DOAJ / DRJI / JOURNAL INDEX / I2OR / SCIENCE LIBRARY INDEX / Google Scholar / Crossref /

Academic Keys / ROAD Open Access / OAJI / Academic Resources / Scientific Indexing Services / SCIPIO

are selected along the coastline of Black and Mediterranean Sea.These five locations are identified as Iğneada, Sinop, Hopa, Alanya, Karatağ. Data used in this study is obtained from the ECMWF Data Server[5].The data is obtained for the area bounded by throughout $10 \mathrm{E}$ to $43 \mathrm{E}$ and $30 \mathrm{~N}$ and $46 \mathrm{~N}$ geographical coordinates which includes the coastline of Turkey. The data period is between 01.01.1996 to 31.12.2008, totally 156 months in length significant height of swell wave and mean period[6].

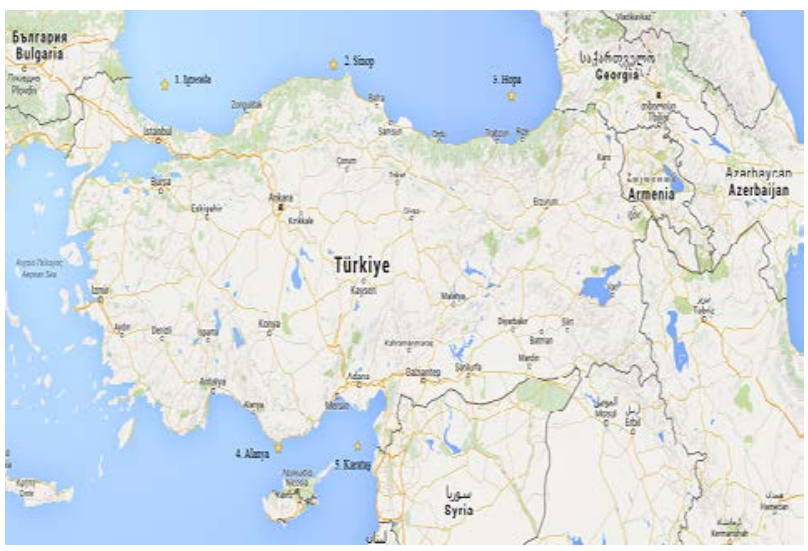

Figure 1: Five different coastal regions are selected along the coastline of Black and Mediterranean Sea

1. A Location at Iğneada Region (GRID $39 \times 25$ ;29.176 ${ }^{\circ} \mathrm{E}-41.885^{\circ} \mathrm{N}$ )

The selected area at Iğneada Region's coorditanetsare $29.176^{\circ} \mathrm{E}-41.885^{\circ} \mathrm{N}$ (at 39x25 grid nodes). For this selected area the relationship between Significant Wave Height $(\mathrm{Hs})$ and Mean Wave Period (Tm) are given for swell wave in Figure 2.As can be seen from the Figure 2, swell wave height is $2.5 \mathrm{~m}$ and maximum swell wave height is 3.95 moreover, significant wind wave height can be seen in Figure 3 as 6.92 meters[6].

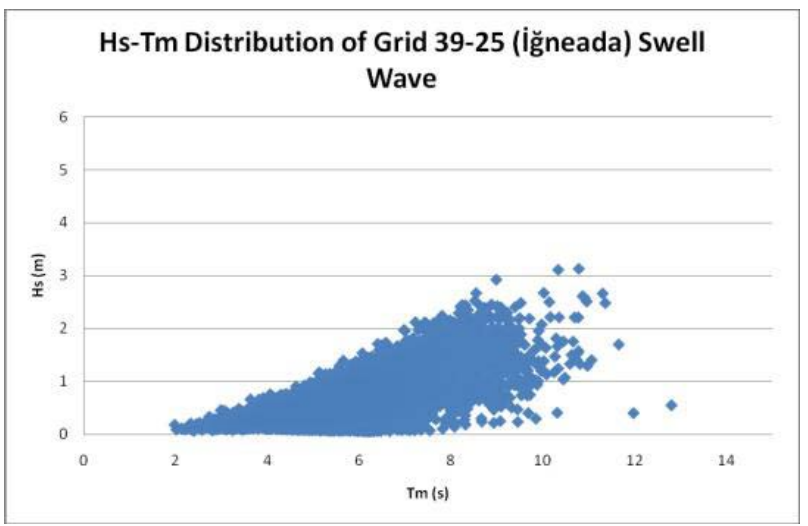

Figure 2: Relationship between Mean Period \& Significant Height of Swell Wave in Iğneada[6].
Hs-Tm Distribution of Grid 39-25 (İğneada) Wind Wave

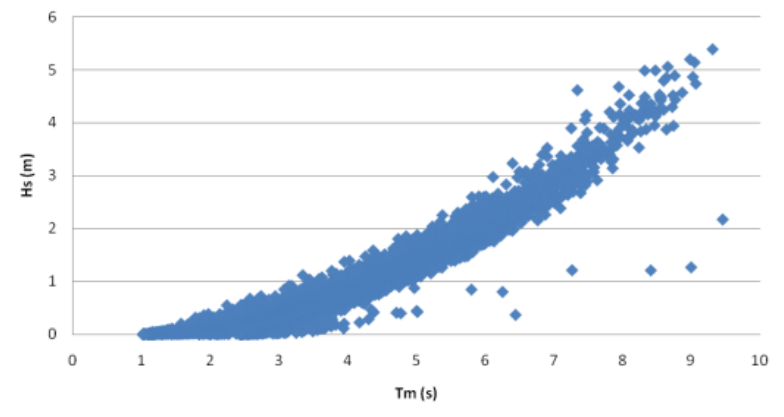

Figure 3: Relationship between Mean Period \& SignificantHeight of Wind Wave in Iğneada [6].

2. A Location at Sinop Region (GRID 49x2; $34.528^{\circ} \mathrm{E}-42.202^{\circ} \mathrm{N}$ )

The selected area at Sinop Region's coordinatesare $34.528^{\circ} \mathrm{E}-42.202^{\circ} \mathrm{N}$ (at $49 \times 26$ grid nodes). For this selected area the relationship between Significant Wave Height (Hs) and Mean Wave Period (Tm) are given for swell wave in Figure 4. \&

Figure 4: Relationship between Mean Period

Significant Height of Swell Wave in Sinop[6].

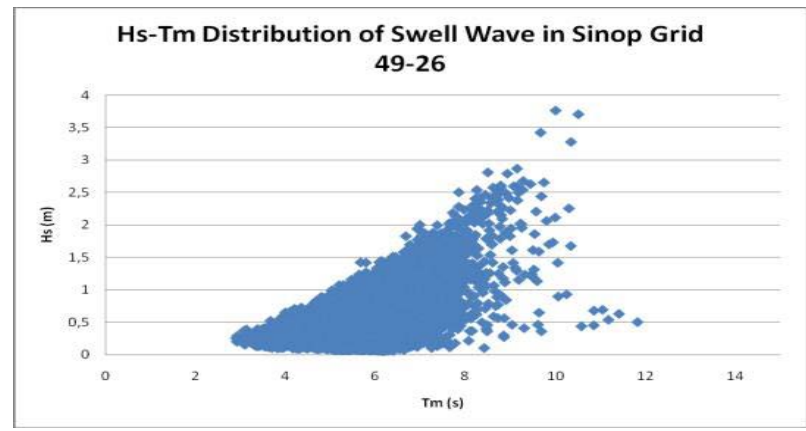

As can be seen from the Figure 4, swell wave height is $3 \mathrm{~m}$ and maximum swell wave height is 3.76 moreover, significant wind wave height can be seen in Figure 5 as 6.32 meters[6] 
"Mircea cel Batran" Naval Academy Scientific Bulletin, Volume XIX - 2016 - Issue 1

Published by "Mircea cel Batran" Naval Academy Press, Constanta, Romania // The journal is indexed in: PROQUEST / DOAJ / DRJI / JOURNAL INDEX / I2OR / SCIENCE LIBRARY INDEX / Google Scholar / Crossref / Academic Keys / ROAD Open Access / OAJI / Academic Resources / Scientific Indexing Services / SCIPIO

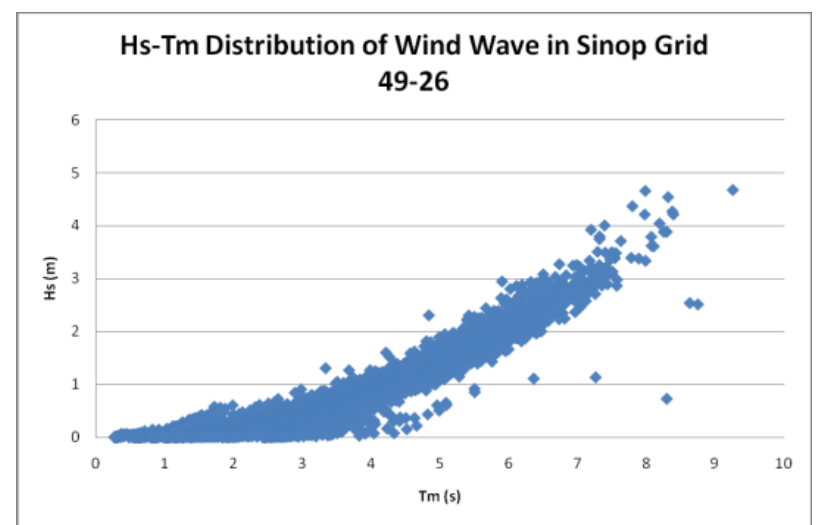

Figure 5:Relationship between Mean Period \& Significant Height of Wind Wave in Sinop[6].

\section{A Location at Hopa Region (GRID 61x25 ; $\left.40.161^{\circ} \mathrm{E}-41.715^{\circ} \mathrm{N}\right)$}

The selected area at Hopa Region's coordinatesare $40.161^{\circ} \mathrm{E}-41.715 \mathrm{~N}$ (at $61 \times 25$ grid nodes). For this selected area the relationship between Significant Wave Height (Hs) and Mean Wave Period (Tm) are given for swell wave in Figure 6.As can be seen from the Figure 6 , swell wave height is $2.5 \mathrm{~m}$ and maximum swell wave height is $3.48 \mathrm{~m}$.Moreover, significant wind wave height can be seen in Figure 7 as 4.83 meters[6].

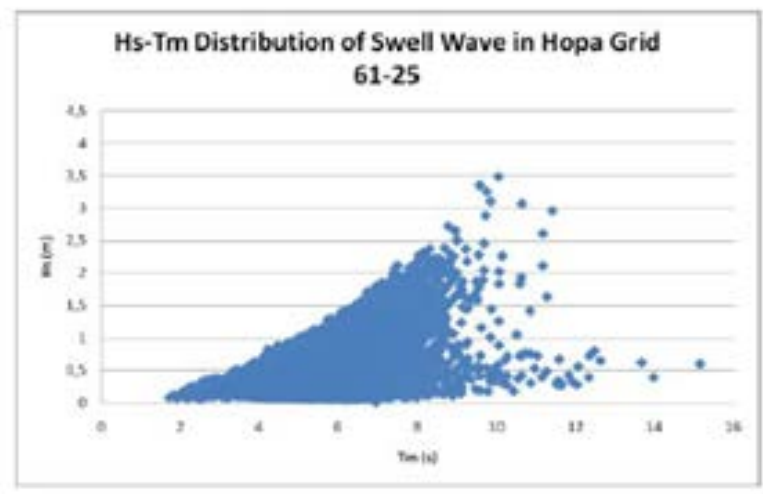

Figure 6: Relationship between Mean Period \& Significant Height of Swell Wave in Hopa[6].

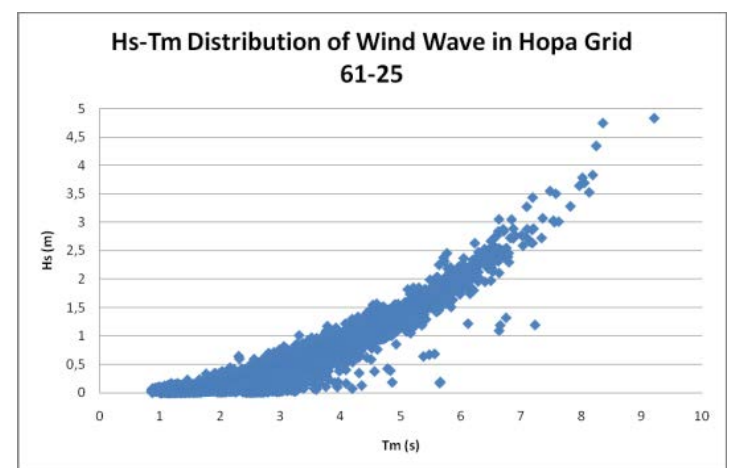

Figure 7: Relationship between Mean Period \& Significant Height of Wind Wave in Hopa[6].

4.A Location at Alanya Region (GRID 46x13 ; $\left.32.775^{\circ} \mathrm{E}-35.93^{\circ} \mathrm{N}\right)$

The selected area at Alanya Region's coordinatesare $32.775^{\circ} \mathrm{E}-35.93^{\circ} \mathrm{N}$ (at $46 \times 13$ grid nodes). For this selected area the relationship between Significant Wave Height (Hs) and Mean Wave Period (Tm) are given for swell wave in Figure 8.As can be seen from the Figure 8, swell wave height is $2.5 \mathrm{~m}$ and maximum swell wave height is 3.62 moreover, significant wind wave height can be seen in Figure 9 as 4.8 meters.

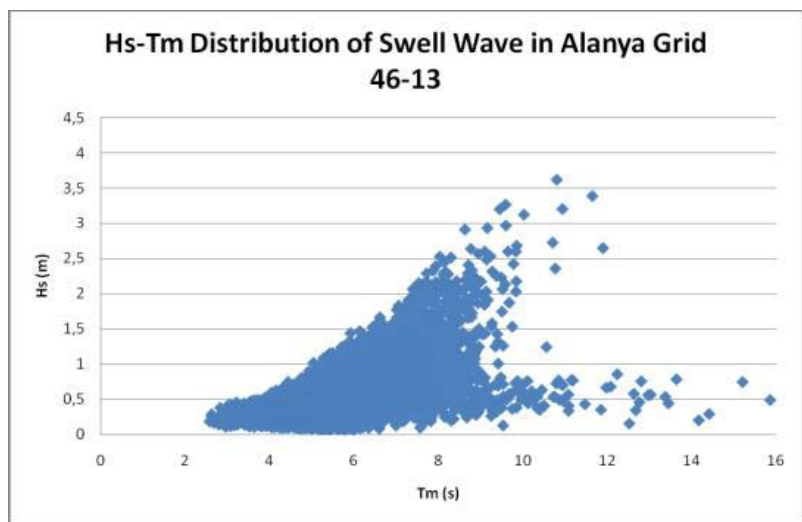

Figure 8: Relationship between Mean Period \& Significant Height of Swell Wave in Alanya [6].

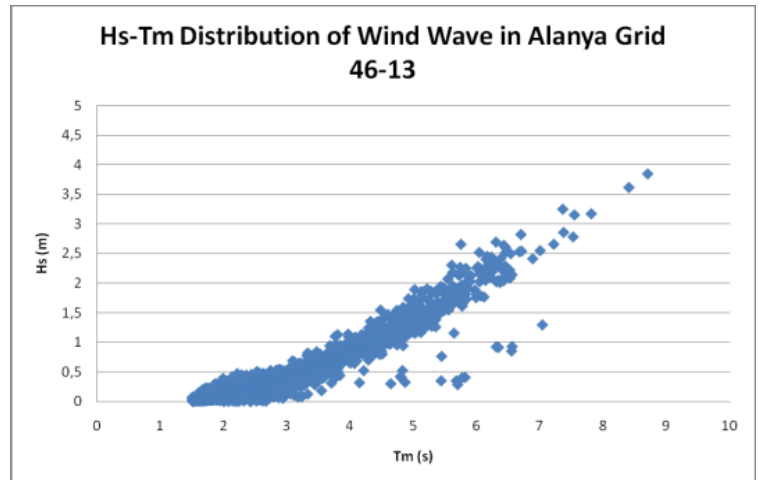

Figure 9:Relationship between Mean Period\& Significant Height of Wind Wave in Alanya[6]. 
"Mircea cel Batran" Naval Academy Scientific Bulletin, Volume XIX - 2016 - Issue 1

Published by "Mircea cel Batran" Naval Academy Press, Constanta, Romania // The journal is indexed in:

PROQUEST / DOAJ / DRJI / JOURNAL INDEX / I2OR / SCIENCE LIBRARY INDEX / Google Scholar / Crossref /

Academic Keys / ROAD Open Access / OAJI / Academic Resources / Scientific Indexing Services / SCIPIO

\section{A Location at Karataş Region (GRID 51x13 ;} $\left.35.30^{\circ} \mathrm{E}-35.968^{\circ} \mathrm{N}\right)$

The selected area at Karataş Region's coordinates are $35.30^{\circ} \mathrm{E}-35.968^{\circ} \mathrm{N}$ (at $51 \times 13$ grid nodes). For this selected area the relationship between Significant Wave Height (Hs) and Mean Wave Period (Tm) are given for swell wave in Figure 10.As can be seen from the Figure 10, swell wave height is $2 \mathrm{~m}$ and maximum swell wave height is 3.40 moreover, significant wind wave height can be seen in Figure 11 as 5.11 meters[6].

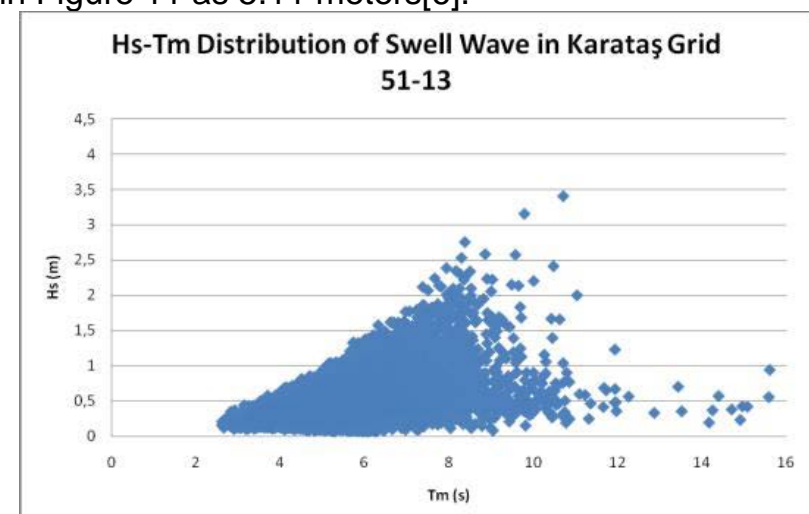

Figure 10: Relationship between Mean Period \& Significant Height of Swell Wave in Karataş [6].

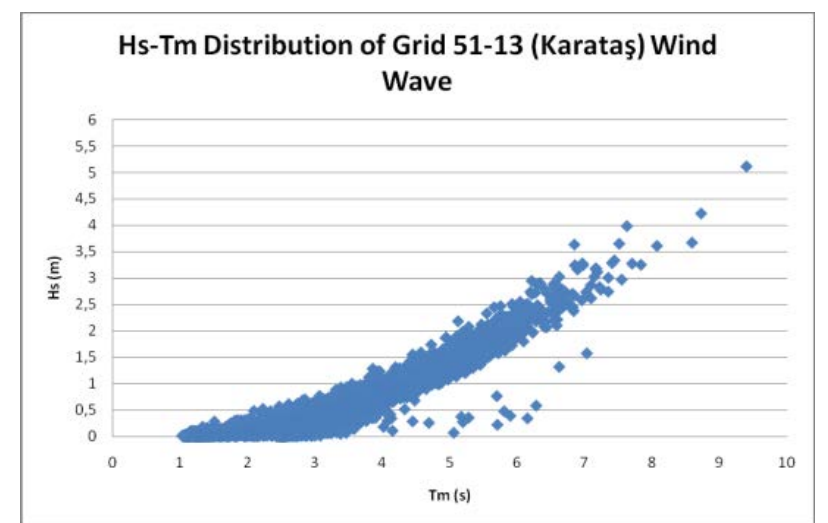

Figure 11: Relationship between Mean Period \& Significant Height of Wind Wave in Karataş [6].

As shown in the graphs the wave energy density is the highest winter and autumn, fortunately coinciding with the greatest energy demands. As set forth in this study, in certain coastal areas, wave energy can be generated at usable scale. The regions in the west of the Black Sea in the north of Istanbul Straits have been suggested as the best sites to harness the wave energy. Wave farms can be set up at two main regions north-west (Iğneada region) and north (Sinop region) among selected five regions in this study[6].For the study, Igneada Region have been selected for calculation of how much electricity needs can be met by using wave energy converter system.

\section{SUITABLE WAVE ENERGY CONVERTER FOR}

\section{IGNEADA REGION}

An oscillating water column (OWC) is a wave energy converting technology that can be installed onshore preferably on rocky shores; nearshore in up to $10 \mathrm{~m}$ of water; or offshore in 40-80m deep water. The device consists of a large wave capture chamber, a platform for an air turbine, a lip, wing walls, and an air chamber. When waves approach the device, they enter under the partially submerged lip that traps air in a piston type system, forcing the air upwards through the air turbine. This pressure forces the turbine to spin, which is how the energy is harnessed by the waves. As the waves retreat, air enters back into the air chamber from the other side of the turbine [7].

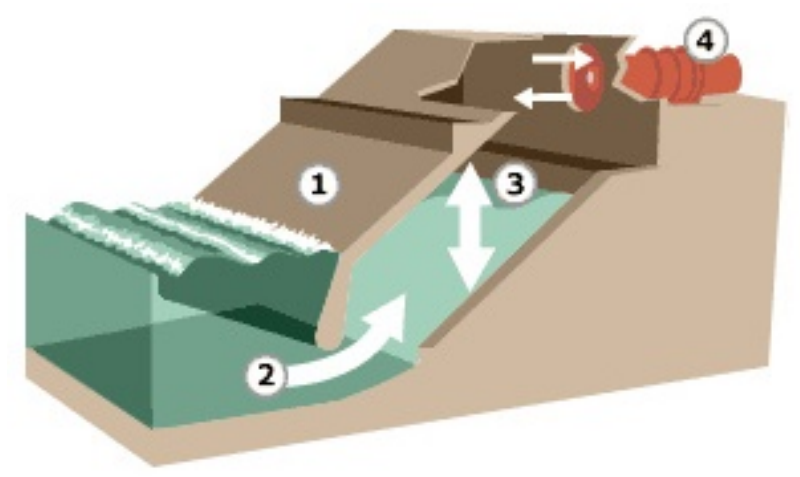

1. Wave capture chamber set into rock face

2. Tidal power forces water into chamber

3. Air alternately compresssed and decompressed by "oscillating water column"

4. Rushes of air drive the Wells Turbine, creating power

Figure 12:OWC system and working principle [7].

There are many examples of OWC system in the world. The LIMPET, which is the OWC located on the coast of Islay, Scotland, is currently operating as a prototype at $75 \mathrm{~kW}$. However, the facility is able to work at a full capacity of $500 \mathrm{~kW}$.This is the generating capacity that makes wave energy economically viable and able to compete in the commercial market [8]. The site in India built as a nearshore OWC is operating at $150 \mathrm{~kW}$. The Mk3-PC built by Oceanlinx was rated to $2.5 \mathrm{MW}$. The stark differences depend on the construction, air turbine, and wave energy available. Wave energy is currently quite expensive operating at 14 cents per kWh. This is due partly to the expensive installation costs and technology development. Eventually as wave energy become more wide spread the cost will be lowered to a price comparable to wind 
"Mircea cel Batran" Naval Academy Scientific Bulletin, Volume XIX - 2016 - Issue 1

Published by "Mircea cel Batran" Naval Academy Press, Constanta, Romania // The journal is indexed in:

PROQUEST / DOAJ / DRJI / JOURNAL INDEX / I2OR / SCIENCE LIBRARY INDEX / Google Scholar / Crossref /

Academic Keys / ROAD Open Access / OAJI / Academic Resources / Scientific Indexing Services / SCIPIO

energy[7].

\section{THE AMOUNT OF ELECTRICITY CAN BE MET BY OWC SYSTEM}

Some wave height distributions were obtained fromthe publication of "Turkish Office of Navigation, Hydrography and Oceanography". According to the published values ofsignificant wave heights $(\mathrm{Hs})$ for Black Sea are found as1,2835 m.12th International Towing Tank Conference (ITTC) in 1969 recommended using a new spectrum because of the mixed sea's unknown characteristic wave heights. The coefficients used in the spectrum are A and B.

$$
\begin{aligned}
& A=8,1 * 10^{-3} * g^{2} \\
& B=\frac{3,11}{H_{1 / a}^{2}}=\frac{3,11}{H_{g}^{2}}
\end{aligned}
$$

Using this value, the coefficients $A$ and $B$ for the ITTC Spectrum will be obtained as $B=1,887855$ and $A=0,77951241$ respectively.

Substituting these values into theBretschneider Spectrum, One gets the frequency as $\omega=1,10857$ $\mathrm{s}^{-1}$.

$B=\frac{5 * \omega^{4}}{4}$

$T=\frac{2 \pi}{\omega}$

$\lambda=\frac{g T^{2}}{2 \pi}$

The corresponding wave period, from equation (4), will be found as $T=5.6678$ seconds. Since the water is assumed to be deep water, the wave length will be obtained from equation (5) as $\lambda=50$. As it is well known that the boundary condition for deep sea is given by $h / \lambda \geq 0,5$. Thus the water depth will become $h \geq 25,077$. From this condition, the water depth can be taken approximately as $\mathrm{h}=26 \mathrm{~m}$. If the value of $\omega$ is taken into consideration as a $1,108571 / \mathrm{s}$,the submerged column's length will be found as $L=4 \mathrm{~m}$. Submerged column's length $(\mathrm{L})$ and column's diameter(D) indicates water volume inside the column. The relationship between $D$ and $\mathrm{L}$ is shown in Figure 11.

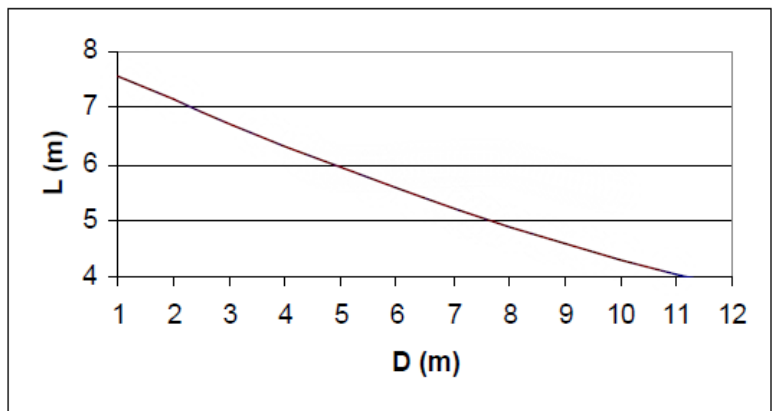

Figure 11:The relationship between $D$ and $L$ [9]. Figure 11 states that if the column's underwater length gets shorter, column's diameter becomesbigger to obtain the some power. The column's underwater length had been founded as $L=4 \mathrm{~m}$ so the diameter of column can only be changed. The wave power obtained by changing the column diameter is shown in Figure 12.

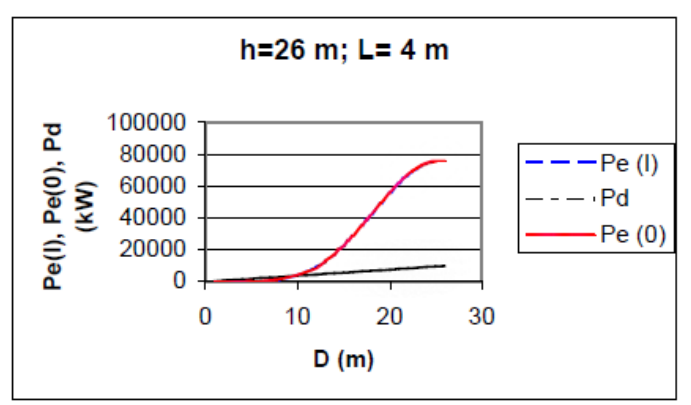

Figure 12:The relationship between $D$ and $L$ [9].

The $\mathrm{Pe}$ ( wave power ) is shown in two different places in Figure 12. The first one which is given byPe(0) shows thatColumn's power of the bottom opening where remaining inside the water and the other one given by $\mathrm{Pe}(\mathrm{I})$ shows that column's water power which had been absorbed inside.

In this study Thecolumn length, $\mathrm{L}=4 \mathrm{~m}$, had been used. As a result of $L ; D$ is found as $11.2 \mathrm{~m}$. It can be said that the most optimistic estimate of losses is $\% 40$ of total the power that comes from turbine. From Figure 12, the power that can be transmitted to the turbine $P d=6300 \mathrm{~kW}$ for $D=11 \mathrm{~m}$. In case of approximate power losses and costs, the amount of energy that can be converted into electrical energy, thought to be around $200 \mathrm{~kW}$ [9]. The daily total power consumption of one house was identified as $6.39 \mathrm{~kW}[10]$.As a result of this, approximately 30 houses daily electrical needs can be obtained by OWC system atlgneada Region. 


\begin{abstract}
"Mircea cel Batran" Naval Academy Scientific Bulletin, Volume XIX - 2016 - Issue 1 Published by "Mircea cel Batran" Naval Academy Press, Constanta, Romania /I The journal is indexed in: PROQUEST / DOAJ / DRJI / JOURNAL INDEX / I2OR / SCIENCE LIBRARY INDEX / Google Scholar / Crossref / Academic Keys I ROAD Open Access / OAJI / Academic Resources / Scientific Indexing Services / SCIPIO
\end{abstract}

\title{
CONCLUSIONS
}

Having the maximum benefit from the installed wave energy converters, it is important to find a location where the minimum variation between the peak season and the low season is obtained. Seasonality is a factor which can affect the feasibility of a wave energy project. The results of analysis are given for the five selected regions around Turkey's coast.

The results have shown that Igneada region is the best location within the five selected region to generate electrical energy from the absorber type wave energy converters.

Selection type of wave converter is the best for a particular location that depends on a large number of variables including wave power, water depth, region, and climate.Although it is highly variable with some devices. It can be well suitable for some locations, but not for the other regions.

A wide variety of technologies related to wave converter systems has been proposed, investigated, and in some cases tested at full size in real ocean conditions. Oscillating water column (OWC) devices, of fixed structure or floating, are an important type of wave energy devices comparing with the other systems. There are many successful examples in the world.

In this study, the OWC wave converter system was selected since it is appropriate to the region conditions. Finally, aftertheiğneada region's wave energy potential is calculated, the amount of energy generated from OWC systemis found tomeet the needs of 30 homes energy requirements.

The electricity requirement of Igneada area needs more than the calculated values. It can be achieved by the establishment of wave energy farm system. The availability and capacity of this system is found by a prototype model experiment to be carried out.

\section{BIBLIOGRAPHY}

[1] IEA. International Energy Agency. In: World energy outlook 2009. Paris: IEA; 2009

[2] "Global wind energy markets continue to boom - 2006 another record year," Press release of Global Wind Energy Council (GWEC), Bruxelles (Belgium), 02.02.2007.

URL: http://www.gwec.net/uploads/media/07-02 PR Global Statistics 2006.pdf.

[3] Callaghan, J., "Future Marine Energy Results of the Marine Energy Challenge: Cost competitiveness and growth of wave and tidal stream energy," Research Report, Carbon Trust, London (UK), 2006. URL: http://oreg.ca/docs/Carbon\%2Trust\%20Report/FutureMarineEnergy.pdf.

[4] Thorpe, T.W., "An Overview of Wave Energy Technologies" Report AEAT-3615, Office of Science and Technology, AEA Technology, 1999.

[5] ECMWF, 2008

[6] Duman, Cağatay "Evaluation and Comparison of the Wave Energy Potential In Selected Coastal Regions in Turkey", Middle East Technical University, Master Thesis,2010

[7] http://coastalenergyandenvironment.web.unc.edu/ocean-energy-generating-technologies/waveenergy/oscillating-water-column/

[8] Carbon Trust. Shoreline and Nearshore OWC Wave Energy Devices. Rep. N.p.: n.p., 2010. Docstoc.Web. 25 July 2012.

[9]Bak,Ufuk. "Conversion Systems From Wave Energy to Electrical Energy",Istanbul Technical

Universty,Master Thesis,2003

[10]Gökçöl, Cihan ;Sunan, Erkan; Dursun, Bahtiyar. "Wind Energy Usage in a House in Gebze" Gebze Technical Universty 